\title{
Assessment of the Effectiveness of Pre-harvest Meat Safety Interventions to Control Foodborne Pathogens in Broilers: a Systematic Review
}

\author{
Joana Pessoa ${ }^{1,2} \cdot$ Maria Rodrigues da Costa $^{3} \cdot$ Truls Nesbakken $^{4} \cdot$ Diana Meemken $^{5}$ (D) on behalf of the RIBMINS Cost \\ Action
}

Accepted: 29 January 2021 / Published online: 14 February 2021

(C) The Author(s) 2021

\begin{abstract}
Purpose of Review Ensuring broilers' meat safety is a priority to policy makers, producers, and consumers. This systematic review aims to update the recent knowledge on pre-harvest interventions to control main foodborne pathogens in broilers and to assess their effectiveness.

Recent Findings A total of 815 studies were retrieved from PubMed® and Web of Science for 13 pathogens. In total, 51 studies regarding Campylobacter spp., Salmonella spp., VTEC, ESBL-AmpC Escherichia coli, and Clostridium perfringens were included in this review.

Summary Research mostly focused on Salmonella spp. and Campylobacter spp. Biosecurity and management interventions had mixed outcomes, while the effectiveness of feed additives, though intensively researched, remains controversial. Research on other pathogens (i.e. ESBL-AmpC E. coli/Salmonella, and Toxoplasma gondii) was scarce, with publications focusing on epidemiology and/or on source-attribution studies. This is also true regarding research on Listeria monocytogenes, Bacillus cereus, Clostridium botulinum, Clostridium perfringens, and Staphylococcus aureus as these are frequently controlled by post-harvest interventions. Overall, studies on recent developments of novel pathogen-specific immunisation strategies are lacking.
\end{abstract}

Keywords Campylobacter $\cdot$ Farm practices $\cdot$ Poultry $\cdot$ Salmonella $\cdot$ Zoonoses

\section{Introduction}

Worldwide, poultry meat consumption is growing rapidly and has surpassed pork as the preferred animal protein source in

This article is part of the Topical Collection on Bacteriology

Diana Meemken

Diana.Meemken@fu-berlin.de

Joana Pessoa

Joana.Pessoa@teagasc.ie; Joana.Cardosapessoa@ucdconnect.ie

Maria Rodrigues da Costa

Maria.Costa@sruc.ac.uk

Truls Nesbakken

Truls.Nesbakken@nmbu.no

$1 \quad$ Pig Development Department, Teagasc, Animal and Grassland Research and Innovation Centre, Moorepark, Fermoy, Co, Cork, Ireland
2016 [1]. Among poultry meat products, broiler meat is the most consumed. Therefore, ensuring the safety of broiler meat and broiler meat products is a priority to policy makers, producers, and consumers.
2 Section of Herd Health and Animal Husbandry, University College Dublin, School of Veterinary Medicine, Dublin, Belfield, Dublin 4, Ireland

3 Epidemiology Research Unit, Department of Veterinary and Animal Science, Northern Faculty, Scotland's Rural College (SRUC), An Lòchran, 10 Inverness Campus, Inverness, Scotland IV2 5NA, UK

4 Faculty of Veterinary Medicine; Department of Production Animal Clinical Sciences, Norwegian University of Life Sciences, P.O. Box 5003, 1432 Ås, Norway

5 Institute of Food Safety and Food Hygiene, Working Group Meat Hygiene, Freie Universität Berlin, Königsweg 67, 14163 Berlin, Germany 
In 2012, the European Food Safety Authority (EFSA) issued a scientific opinion on the public health hazards to be covered by inspection of poultry. This document contained a list of 13 biological hazards (Table 1) that can be transmitted to humans through the handling, preparation, and/or consumption of broiler meat and meat products [2]. Among these were Campylobacter spp. and Salmonella spp., which have been the two most frequently reported human gastrointestinal bacterial pathogens in Europe for the past decade [3]. Indeed, while several potential transmission routes for these two pathogens exist, broilers have been identified as the main reservoir for Campylobacter [4], and are also an important food vehicle for Salmonella [5].

Although less commonly reported as causes of human foodborne illnesses, Bacillus cereus, Clostridium botulinum, Clostridium difficile, Clostridium perfringens, verotoxinproducing Escherichia coli (VTEC), Listeria monocytogenes, Staphylococcus aureus enterotoxins, Yersinia enterocolitica, and Toxoplasma gondii are also liable to cause infections, intoxications, or toxicoinfections through the consumption of contaminated broiler meat [2]. Furthermore, extended spectrum $\beta$-lactamase (ESBL)/AmpC gene carrying E. coli were considered to be of medium to high relevance to public health, while ESBL/AmpC gene carrying Salmonella were considered to be of low to medium relevance [2].

As these 13 pathogens continue to pose a threat to public health, control options using a farm to fork approach are needed to minimise the risk and spread of foodborne diseases by consumption of broiler meat. Pre-harvest interventions take place on-farm and/or during transport of animals to slaughter and aim to minimise the introduction, persistence, and transmission of foodborne pathogens into broiler flocks. Indeed, several studies have shown that reducing the prevalence and/ or the concentration of pathogens in primary broiler production would result in greater public health benefits than interventions at later stages in the food chain [4-6].

Pre-harvest interventions can be divided into two main categories that aim to (1) reduce the prevalence of flocks contaminated with a specific pathogen, and (2) reduce the concentration of a pathogen in broilers belonging to contaminated flocks.

In the first group, the main intervention strategies are related to external biosecurity measures, which prevent the introduction of a pathogen into a farm. Key interventions focus on breeding animals free from selected pathogens at the top of the breeding pyramid, the control of feed and water supplies, and implementing physical barriers that restrict access to broiler houses and the external environment around farms [6, 7]. Internal biosecurity, where high hygiene is implemented through good cleaning and disinfection protocols, is also an important preventative measure [7].

In the second group, several interventions focus on increasing host resistance to reduce pathogen load in the caeca and on the use of antimicrobial alternatives to reduce or eliminate selected pathogens from colonised broilers. Research in this area has focused on studying and developing new control strategies such as the use of feed and water additives, the application of bacteriophages, vaccination, bacteriocins, and competitive exclusion [8-12].

Table 1 Keyword search and flow of information through the systematic review for 13 foodborne pathogens

\begin{tabular}{|c|c|c|c|c|c|}
\hline Pathogen & Keyword searched & $\begin{array}{l}\text { Records } \\
\text { identified }\end{array}$ & $\begin{array}{l}\text { Records after } \\
\text { duplicate removal }\end{array}$ & $\begin{array}{l}\text { Records retained } \\
\text { after abstract } \\
\text { screening }\end{array}$ & $\begin{array}{l}\text { Records retained } \\
\text { after full text } \\
\text { screening }\end{array}$ \\
\hline B. cereus & bacillus cereus & 3 & 3 & 0 & 0 \\
\hline Campylobacter & $\begin{array}{l}\text { campylobacter* OR “campylobacter jejuni” OR } \\
\text { "campylobacter coli” }\end{array}$ & 230 & 208 & 34 & 24 \\
\hline C. botulinum & clostridium botulinum OR botulism & 3 & 2 & 0 & 0 \\
\hline C. difficile & $\begin{array}{l}\text { clostridium difficile OR c. difficile OR } \\
\text { clostridioides difficile }\end{array}$ & 0 & 0 & 0 & 0 \\
\hline C. perfringens & $\begin{array}{l}\text { clostridium perfringens OR c. perfringens OR } \\
\text { clostridial diarrh* }\end{array}$ & 23 & 22 & 5 & 3 \\
\hline ESBL-Amp C E. coli & $((\mathrm{ESBL} * \mathrm{OR}$ AmpC) AND E. coli) & 57 & 53 & 6 & 2 \\
\hline ESBL-Amp C Salmonella & ((ESBL* OR AmpC) AND salmonella) & 9 & 9 & 0 & 0 \\
\hline Listeria monocytogenes & listeria monocytogenes OR listeriosis & 14 & 13 & 0 & 0 \\
\hline MRSA & $\begin{array}{l}\text { methicillin resistant staphylococcus aureus } \\
\text { OR MRSA OR resistant s.aureus }\end{array}$ & 17 & 17 & 0 & 0 \\
\hline Salmonella spp. & salmone* & 301 & 282 & 33 & 20 \\
\hline VTEC & $\begin{array}{l}\text { Escherichia coli OR toxicoinfectious E. coli } \\
\text { OR VTEC }\end{array}$ & 201 & 191 & 8 & 1 \\
\hline Y. enterocolitica & Yersini* & 6 & 6 & 0 & 0 \\
\hline T. gondii & toxoplasma gondii OR toxoplasmosis & 10 & 9 & 0 & 0 \\
\hline
\end{tabular}


This review of literature published between 2015 and 2020 aims to update the knowledge on pre-harvest interventions to control 13 public health hazards enlisted in EFSA's report, and to assess their effectiveness.

\section{Materials and Methods}

This systematic review was based on EFSA guidelines issued for "those carrying out systematic reviews" for food and feed safety assessments [13], and on the methodology proposed in the PRISMA (Preferred Reporting Items for Systematic Reviews and Meta-Analyses) statement [14].

Literature searches were carried out on PubMed ${ }^{\circledR}$ and Web of Science on June 7th, 2020, including peer-reviewed studies written in English and published between 2015 and 2020 (until June 7 th) on the effectiveness of pre-harvest meat safety interventions to control 13 foodborne pathogens. The 5-year timeframe was introduced as a Journal requirement and narrowed down this systematic review to focus on the most recent research tackling the control of foodborne pathogens on-farm or during transport. All searches were restricted to title and abstract. The structure of the search strings used in each database is shown in Fig. 1, and each search had pathogen-specific keywords, as shown in Table 1. The detailed search strings used for each database can be assessed in the supplementary material.

All records were imported into EndNote and duplicates were removed. One co-author screened abstracts using a defined set of inclusion and exclusion criteria (Table 2). In a second phase, full texts of all remaining references were retrieved and screened in parallel by two co-authors, using the same eligibility criteria (Table 2). For any record to be removed, both co-authors had to agree on its exclusion. If agreement was not attained, a third co-author reviewed the full text and made the final decision. The flow of information through the systematic review process is shown in Table 1.

A Microsoft Office Excel spreadsheet documented the classification of studies based on the intervention described and other relevant information, such as follows: country and year where/when the study took place; type of experimental study (challenge or field studies); type (i.e. animal, flock, environmental) and number of experimental units; sample type; type of outcome measured; and estimate of the effectiveness of each intervention. For this systematic review, "study" was defined as any primary research peer-reviewed publication, in which the authors had collected, analysed, and reported their own data. On several occasions, we found that within the same study, authors evaluated the efficacy of different interventions. Therefore, within each study, several trials could be reported (defined as the unique treatment-to-control comparisons made), and whenever possible, trial-specific information was collected. Whenever the outcome of an intervention was measured through several time-points, data collected at the end of the study were preferred.

\section{Results}

A total of 815 unique studies were retrieved through the search strings run on PubMed® and Web of Science for the 13 pathogens included in this study. Salmonella spp., Campylobacter spp., and VTEC were the pathogens for which the largest number of studies was found (Table 1), while C. difficile, $C$. botulinum, and B. cereus had the fewest, with zero, two, and three studies, respectively. After the abstract-based screening, only five pathogens remained. These were as follows: Campylobacter spp. ( $n=34$ studies), Salmonella spp. ( $n=33$ studies), VTEC ( $n=8$ studies), ESBL-AmpC E. coli $(n=6$ studies), and $C$. perfringens ( $n=5$ studies). Full texts were then retrieved for further evaluation. Even though 86 studies passed
Fig. 1 Search string structure used for the searches conducted in PubMed® and the Web of Science databases on June 7 th, 2020. The detailed search strings used are provided as supplementary material

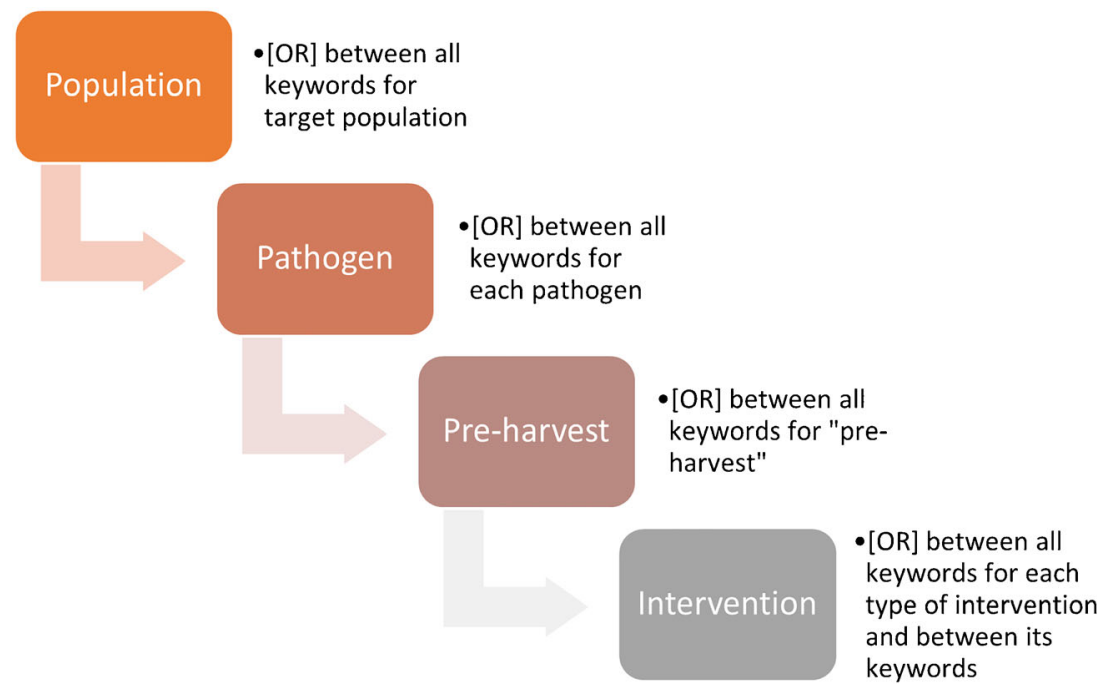


Table 2 Eligibility (inclusion and exclusion) criteria used for the screening of title/abstracts and full texts

\begin{tabular}{|c|c|c|}
\hline $\mathrm{PICO}^{\mathrm{a}}$ & Inclusion & Exclusion \\
\hline \multirow[t]{2}{*}{ Population } & $\begin{array}{l}\text { Animal species being evaluated: must include (but } \\
\text { not limited to) broilers }\end{array}$ & $\begin{array}{l}\text { Does not include actual or theoretical } \\
<\text { pathogen }>\text { infection/contamination } \\
\text { in broilers }\end{array}$ \\
\hline & $\begin{array}{l}\text { Unit of study (animal, flock, house, farm and } \\
\text { surfaces, food, water, environment, drinkers, } \\
\text { feeder, other animals) }\end{array}$ & Others \\
\hline \multirow[t]{3}{*}{ Intervention } & $\begin{array}{l}\text { Interventions to control/reduce/eradicate } \\
<\text { pathogen }>\text { in broilers }\end{array}$ & $\begin{array}{l}\text { Studies not mentioning } \\
\text { control/reduce/eradicate interventions } \\
\text { for }<\text { pathogen }>\text { in broilers }\end{array}$ \\
\hline & $\begin{array}{l}\text { Interventions on-farm or during transport } \\
\text { (pre-harvest) }\end{array}$ & $\begin{array}{l}\text { Interventions on lairage, at slaughter and } \\
\text { post-harvest }\end{array}$ \\
\hline & Field/experimental studies & Lab/bench studies \\
\hline Comparison & $\begin{array}{l}\text { Control group present (group subjected to no } \\
\text { intervention) }\end{array}$ & Control group absent \\
\hline Outcomes & $\begin{array}{l}\text { Provides some measure of the efficacy of the } \\
\text { intervention }\end{array}$ & Efficacy of the intervention not measured \\
\hline \multirow[t]{2}{*}{ Others } & Language: English & Other languages \\
\hline & Peer reviews & Grey literature \\
\hline
\end{tabular}

${ }^{\text {a }}$ PICO (participants, interventions, comparisons, and outcome(s)) constitutes the framework in which research questions are formulated, as proposed in the PRISMA statement [14] the initial screening, one full text could not be retrieved, and 34 other studies were discarded during full text evaluation. Studies with the following characteristics were excluded $(n=34)$ : studies not performed in the target population $(n=14,41 \%)$, studies not mentioning a clear intervention $(n=7,21 \%)$, studies with no control group $(n=7,21 \%)$, studies which did not report a measurable outcome $(n=3,9 \%)$, or in vitro studies $(n=3,9 \%)$. Ultimately, a total of 51 studies (59\% of the initial 86 studies) stratified by five different pathogens (Table 1) were included in this systematic review.

Within the reported studies (i.e. 24 studies regarding Campylobacter spp. and 20 studies regarding Salmonella spp.), a total of 71 and 62 trials on pre-harvest interventions to control Campylobacter spp. and Salmonella spp., respectively, were identified and included in this systematic review. Studies regarding Campylobacter spp. [15-34, 35•, 36-38] and Salmonella spp. [15, 19, 39-56] were carried out in thirteen and eleven different countries, respectively. For both pathogens, most of the pre-harvest interventions were assessed in lab-based challenge trials (65\% and $82 \%)$, while the remaining trials were field trials where no experimental infection was performed. Characteristics of these trials are summarised in Table 3.

Overall, the most common interventions to control Campylobacter were those evaluating the effect of feed additives (49\%), followed by cleaning and disinfection programmes (23\%). Regarding Salmonella spp., cleaning and disinfection programmes were the most frequent interventions applied (27\%), followed closely by feed additives (21\%).

All trials measured the effectiveness of each intervention by bacteriological isolation. For both pathogens, the most common unit of measurement was $\log \mathrm{CFU} / \mathrm{g}$, with $61 \%$ and $44 \%$ of trials reporting CFU/g for Campylobacter spp. and Salmonella spp., respectively. Still, many different units quantifying results were used. To overcome this, results were qualitatively characterised concerning the effectiveness of each intervention by considering whether a reduction in the outcome measured could be observed or not (Table 4).

Of the eight types of pre-harvest interventions to control Campylobacter spp. included in this review, only three had a positive effect. Biosecurity interventions proved to be most effective, with $71 \%$ of trials showing a reduction in Campylobacter spp. On the other hand, all biosecurity interventions were ineffective in reducing Salmonella spp., while all trials applying competitive exclusion and $80 \%$ of trials using bacteriophages proved to be effective in significantly reducing Salmonella spp.

Regarding C. perfringens, a total of 27 trials on pre-harvest interventions were identified in the three studies $[16,57,58]$ included in this systematic review. Of those, 26 investigated the use of different feed additives to control this pathogen, while one trial used a drug-free programme with a combination of feed additives, improved water quality, and optimised brooding conditions. Of the 26 trials using feed additives, ten showed a significant reduction in bacterial counts (log CFU/ $\mathrm{g}$ ), while the drug-free programme proved ineffective.

One study, comprising two trials, investigated the use of feed additives and enrofloxacin to control ESBL-AmpC $E$. coli, showing that the first intervention was not effective in significantly reducing this pathogen, while enrofloxacin proved to be effective [59]. The second study investigated the effect of cessation of ceftiofur and its substitution with 
Table 3 Descriptive characteristics of 72 trials from 24 studies and 62 trials from 20 studies investigating pre-harvest interventions to control Campylobacter spp. and Salmonella spp., respectively

\begin{tabular}{|c|c|c|c|}
\hline \multirow[t]{2}{*}{ Variable } & \multirow[t]{2}{*}{ Category } & \multicolumn{2}{|l|}{ \# trials, $n(\%)$} \\
\hline & & Campylobacter & Salmonella \\
\hline \multirow[t]{2}{*}{ On-farm vs. during transport intervention } & On-farm & $63(89)$ & $52(84)$ \\
\hline & Transport coop & $8(11)$ & $10(16)$ \\
\hline \multirow[t]{3}{*}{ Study setting } & Commercial farm & $20(28)$ & $11(18)$ \\
\hline & Commercial plant & $5(7)$ & \\
\hline & Research lab & $46(65)$ & $51(82)$ \\
\hline \multirow[t]{9}{*}{ Type of intervention } & Bacteriophages & $1(1)$ & $5(8)$ \\
\hline & Biosecurity & $7(10)$ & $2(3)$ \\
\hline & Cleaning \& disinfection & $16(23)$ & $17(27)$ \\
\hline & Combination of measures & $1(1)$ & $6(10)$ \\
\hline & Competitive exclusion & - & $3(5)$ \\
\hline & Feed additives & $35(49)$ & $13(21)$ \\
\hline & Litter management & $1(1)$ & $10(16)$ \\
\hline & Oral immunisation & $4(6)$ & - \\
\hline & Vaccination & $6(9)$ & $6(10)$ \\
\hline \multirow[t]{6}{*}{ Sample type } & Caecal & $51(72)$ & $25(40)$ \\
\hline & Cloacal & $1(1)$ & $6(10)$ \\
\hline & Environmental & $9(13)$ & $11(18)$ \\
\hline & Fresh faeces & $1(1)$ & - \\
\hline & Litter & $1(1)$ & $10(16)$ \\
\hline & Transport coop & $8(12)$ & $10(16)$ \\
\hline
\end{tabular}

lincomycin-spectinomycin on the proportion of E. coli isolates harbouring ESBL-AmpC genes, which proved effective initially, but led to an increase in antimicrobial non- $\beta$-lactam resistance of ESBL-AmpC E. coli due to the use of this antibiotic [60].

Lastly, only one study regarding VTEC [61] was identified in this review. It investigated the effectiveness of feed supplementation with Agaricus bisporus in two different

Table 4 Efficacy of pre-harvest interventions to control Campylobacter and Salmonella stratified by type. Effective interventions were those that significantly reduced a measurable outcome

\begin{tabular}{lll}
\hline Type of intervention & \multicolumn{2}{l}{ Efficacy of interventions $\% *$} \\
\cline { 2 - 3 } & Campylobacter spp. & Salmonella spp. \\
\hline Bacteriophages & 0 & 80 \\
Biosecurity & 71 & 0 \\
Cleaning \& disinfection & 50 & 77 \\
Combination of measures & 0 & 17 \\
Competitive exclusion & - & 100 \\
Feed additives & 31 & 31 \\
Litter management & 0 & 50 \\
Oral immunisation & 0 & - \\
Vaccination & 0 & 17
\end{tabular}

* Given as the number of trials with successful outcomes divided by the total number of trials for each intervention-pathogen concentrations (two trials) in the feed, but no statistical analysis was performed to assess if the reduction of VTEC counts reported in the trial using a higher concentration of the feed additive was significant.

\section{Discussion}

In the past 5 years, several studies have been published on preharvest interventions to control foodborne pathogens in broilers. These were mostly focused on two main hazards (Salmonella spp. and Campylobacter spp.), which reflects the high burden of disease associated with these pathogens.

\section{Campylobacter and Salmonella}

In this review, only two studies, in which biosecurity measures were applied to control Campylobacter spp. [15, 18] and Salmonella spp. [15], were identified, and both were carried out in a commercial setting. Dale et al. used a combination of pest control and hygienic actions for farm staff (e.g. hand disinfection, changing boots, house-specific working materials), which were insufficient measures to decrease the prevalence of either pathogen. The other study, focusing on Campylobacter control, encompassed five trials where a "biosecure cube" was installed and prevented contact between the farm-staff and the birds. All trials reported in this study 
were successful in reducing Campylobacter loads. In another review focusing on pre- and post-harvest interventions to control Campylobacter, the implementation of biosecurity measures such as specific hygienic actions targeting farm-staff and drinking water and the restriction of other farm and wild animals were identified as successful interventions [62•]. A study also found the following variables to be independently associated with an increased risk of Campylobacter spp. colonisation using logistic regression analysis: (i) undisinfected water (having the greatest impact); (ii) tending to other poultry prior to entering the broiler house; (iii) tending to pigs before entering the house; (iv) geographic region; and (v) season (autumn vs. other seasons) [6].

On the other hand, Finland, Norway, and Sweden have documented, during more than 25 years, that stringent biosecurity measures targeting Salmonella spp. in poultry at herd level can be successful in controlling this pathogen [63, 64]. Furthermore, it has also been shown that epidemiological and biological differences between Campylobacter spp. and Salmonella spp. result in a greater likelihood of introduction of Campylobacter spp. into broiler flocks at any production stage if there are lapses in biosecurity standards, likely due to a lower number of organisms needed to infect broiler flocks than for Salmonella spp. and the lack of age-related reduced susceptibility [5].

Regarding cleaning and disinfection practices, most trials focused on transport coops, rather than on-farm interventions. For Campylobacter spp., the most successful intervention was implemented on a commercial plant and used a combination of disinfectant and water at $60^{\circ} \mathrm{C}$, achieving reductions of up to $3.6 \log 10 \mathrm{CFU}$ per transport coop and a marked improvement in visual cleanliness [35•]. While for Salmonella spp., all trials were carried out in research institutions (controlled research setting), and the most effective intervention used a combination of slightly acidic electrolysed water and ultraviolet light, obtaining a complete $100 \%$ inactivation of Salmonella on plastic coop surfaces [53].

Overall, many studies tested the use of feed additives such as probiotics, prebiotics, and essential oils in controlling Campylobacter spp. [17, 20, 23, 25-30, 32-34, 65] and Salmonella spp. [42, 46, 51, 54]. Our results showed great variability in the effectiveness of this group of control measures (Table 4), which is in line with several reviews carried out in the past, which conclude that the exact impact of these feed additives is still unknown $[8,12,62,66]$.

Our results also show that, after excluding interventions to control pathogens through improved management, research is lacking on the development of targeted immunisation strategies for each pathogen. This type of intervention takes longer to develop and has the additional challenge of having to address the epidemiology and biological characteristics of each pathogen at study. However, this additional challenge is also what warrants a higher impact as a control intervention if successful.
Regarding vaccination strategies to control Campylobacter spp., we found only one study using an in ovo DNA vaccine, which presented ineffective results [31]. Furthermore, two studies reported different vaccination strategies for the control of Salmonella entericia subsp. enterica serovar Heidelberg $[44,49]$. The first study tested the efficacy of a genetically modified live vaccine, which was able to partially decrease the bacterial load of $S$. Heidelberg in the caecum and its prevalence in the liver/spleen after oral challenge but had limited duration of immunity [44]. The second study investigated if a broiler breeders' vaccination protocol containing two live and two killed vaccines provided adequate protection in the broiler progeny, and if the level of maternal antibody would determine the protective status of broiler progeny. Results showed that broiler breeders' antibody titres wane over time, and therefore, broiler progeny is not protected from early Salmonella colonisation [49].

Given that most studies, including vaccination studies, were performed under controlled research settings, we highlight the need for more large-scale randomised, blinded trials conducted with different vaccination strategies on commercial farms. These would ascertain the efficacy of these interventions under field conditions.

As antimicrobial resistance raises concerns regarding the use of antimicrobials in livestock, interest in alternatives such as bacteriophage therapy has increased. Still, in our review, research on the use of bacteriophages to control Campylobacter and Salmonella was scarce. One study carried out on a commercial farm showed no significant impact of bacteriophage application on Campylobacter loads [37], while for Salmonella, studies carried out on research institutions (controlled research setting) reported that this type of intervention caused significant reductions of the pathogen loads $[55,56]$, which was not verified in a study held in a commercial setting [50]. While bacteriophages may be an alternative for the control of Campylobacter and Salmonella, one of the major disadvantages to widespread on farm bacteriophage application is due to the capacity of pathogens to become resistant to their bacteriophage, especially if the resistant bacteria can persist in the environment and replicate [11]. Indeed, replicable, and effective studies are lacking. Furthermore, the extrapolation of each trial's results to commercial farms may result in even less optimal outcomes due to the inherent difficulties in consistently implementing standard operating procedures (SOPs) in multiple farms/systems.

\section{Other Pathogens}

Interventions to control other less prominent hazards were much less frequent or non-existent, in spite of their relevance as stated in the 2012 EFSA report [2]. Several pathogenspecific factors should be taken into consideration. 
Although broilers are considered a possible reservoir for ESBL-AmpC gene carrying E. coli [2], the public health burden associated with these animals as sources of human infection is still controversial [67]. Therefore, most studies published focus on the epidemiology of this pathogen and on source attribution, whereas interventions for its control are still not a common research topic. Regarding ESBL-AmpC gene carrying Salmonella, information is even more scarce.

Furthermore, human cases of VTEC infection have not been successfully attributed to broilers $[2,68,69]$, and therefore, EFSA has considered that broiler meat constitutes a low risk for public health when considering this pathogen [2].

Although $Y$. enterocolitica has been the third most reported foodborne zoonoses in EU for several years [3], pigs are considered the main reservoir for this pathogen, and broilers have not been identified as a significant source of human infections [70].

In recent years, $T$. gondii has gained attention due to the severe repercussions it can cause in humans (e.g. neonatal or foetal losses and high disability in cases living permanently with the disease due to compromised vision and/or neurological disease; [71]). In a recent review, it was concluded that the risk of ingestion of $T$. gondii cysts in meat from commercially (indoor) reared broilers was low, but a high prevalence of this parasite was found in broilers from free-range farms [72]. In this study, we only considered studies that focused on indoor farms. Still, with the increase of consumers from high income countries who prefer meat from broilers in outdoor holdings as well as locally sourced products, there may be an increased risk to public health, and therefore need for implementation of preventive measures to control this parasite.

Finally, L. monocytogenes, B. cereus, C. botulinum, $C$. perfringens, and $S$. aureus are mainly controlled by postharvest interventions [2], and therefore, it had to be expected that literature on pre-harvest interventions was not abundant.

\section{Conclusion}

The results of this systematic review reflect that the recent research on pre-harvest interventions to control foodborne zoonoses in broilers were mostly focused on Salmonella spp. and Campylobacter spp.

Biosecurity (i.e. pest control) and management (i.e. hygiene, cleaning, and disinfection) interventions had mixed outcomes in controlling these pathogens, and a strong emphasis on (1) adequately implementing the interventions and (2) combining multiple approaches is recommended across the literature for optimum results. In addition, the effectiveness of feed additives (probiotics, prebiotics, and essential oils) has been extensively researched but remains controversial with results showing great variability.
Recent research on other pathogens (i.e. ESBL-AmpC E. coli, ESBL-AmpC Salmonella, and T. gondii) was scarce, focusing mostly on the epidemiology of the disease and/or documenting source-attribution studies. This is also true regarding research on pre-harvest interventions for controlling L. monocytogenes, B. cereus, C. botulinum, C. perfringens, and $S$. aureus as these are mostly controlled by post-harvest interventions.

Overall, research is lacking on the development of targeted immunisation strategies for each pathogen. This is seen as an essential step to control some of the most prevalent pathogens. However, vaccination strategies should always be implemented in combination with other interventions, especially those which are related to best farming practices. Indeed, interventions such as good cleaning and disinfection and strict biosecurity may be enough to prevent the introduction and/ or control less prevalent pathogens.

Supplementary Information The online version contains supplementary material available at https://doi.org/10.1007/s40588-021-00161-z.

Funding This publication is based upon work from COST Action 18105 RIBMINS (www.ribmins.com) supported by COST (European Cooperation in Science and Technology; www.cost.eu), funded by the Horizon 2020 Framework Programme of the European Union. Open Access funding enabled and organized by Projekt DEAL.

\section{Compliance with Ethical Standards}

Conflict of Interest The authors declare no competing interests.

Human and Animal Rights and Informed Consent This article does not contain any studies with human or animal subjects performed by any of the authors.

Open Access This article is licensed under a Creative Commons Attribution 4.0 International License, which permits use, sharing, adaptation, distribution and reproduction in any medium or format, as long as you give appropriate credit to the original author(s) and the source, provide a link to the Creative Commons licence, and indicate if changes were made. The images or other third party material in this article are included in the article's Creative Commons licence, unless indicated otherwise in a credit line to the material. If material is not included in the article's Creative Commons licence and your intended use is not permitted by statutory regulation or exceeds the permitted use, you will need to obtain permission directly from the copyright holder. To view a copy of this licence, visit http://creativecommons.org/licenses/by/4.0/.

\section{References}

Papers of particular interest, published recently, have been highlighted as:

- Of importance

1. OECD/FAO. OECD-FAO Agricultural Outlook 2017-2026. 2017. 
2. EFSA. Scientific Opinion on the public health hazards to be covered by inspection of meat (poultry). EFSA J. 2012;10(6). https:// doi.org/10.2903/j.efsa.2012.2741.

3. EFSA, ECDC. The European Union one health 2018 zoonoses report. EFSA J. 2019;17(12):e05926. https://doi.org/10.2903/j. efsa.2019.5926.

4. EFSA. Scientific Opinion on Campylobacter in broiler meat production: control options and performance objectives and/or targets at different stages of the food chain. EFSA J. 2011;9(4). https://doi. org/10.2903/j.efsa.2011.2105.

5. EFSA. Salmonella control in poultry flocks and its public health impact. EFSA J. 2019;17(2):e05596. https://doi.org/10.2903/j.efsa. 2019.5596

6. Kapperud G, Skjerve E, Vik L, Hauge K, Lysaker A, Aalmen I, et al. Epidemiological investigation of risk factors for Campylobacter colonization in Norwegian broiler flocks. Epidemiol Infect. 1993;111:245-55.

7. Gelaude P, Schlepers M, Verlinden M, Laanen M, Dewulf J. Biocheck.UGent: a quantitative tool to measure biosecurity at broiler farms and the relationship with technical performances and antimicrobial use. Poultry science. 2014;93(11):2740-51. https://doi. org/10.3382/ps.2014-04002.

8. Sahin O, Kassem II, Shen Z, Lin J, Rajashekara G, Zhang Q. Campylobacter in poultry: ecology and potential interventions. Avian Dis. 2015;59:185-200. https://doi.org/10.1637/11072032315-Review.

9. Atterbury RJ, Van Bergen MA, Ortiz F, Lovell MA, Harris JA, De Boer A, et al. Bacteriophage therapy to reduce Salmonella colonization of broiler chickens. Appl Environ Microbiol. 2007;73(14): 4543-9. https://doi.org/10.1128/AEM.00049-07.

10. Totton SC, Farrar AM, Wilkins W, Bucher O, Waddell LA, Wilhelm BJ, et al. A systematic review and meta-analysis of the effectiveness of biosecurity and vaccination in reducing Salmonella spp. in broiler chickens. Food Research International. 2012;45(2): 617-27. https://doi.org/10.1016/j.foodres.2011.09.005.

11. Grant A, Hashem F, Parveen S. Salmonella and Campylobacter: Antimicrobial resistance and bacteriophage control in poultry. Food Microbiol. 2016;53(Pt B):104-9. https://doi.org/10.1016/j.fm. 2015.09.008.

12. Micciche AC, Foley SL, Pavlidis HO, McIntyre DR, Ricke SC. A review of prebiotics against Salmonella in poultry: current and future potential for microbiome research applications. Front Vet Sci. 2018;5:191. https://doi.org/10.3389/fvets.2018.00191.

13. EFSA. Application of systematic review methodology to food and feed safety assessments to support decision making. EFSA Journal. 2010;8(6). https://doi.org/10.2903/j.efsa.2010.1637.

14. Moher D, Liberati A, Tetzlaff J, Altman DG, Group P. Preferred reporting items for systematic reviews and meta-analyses: the PRISMA statement. BMJ. 2009;339:b2535. https://doi.org/10. 1136/bmj.b2535.

15. Dale EL, Nolan SP, Berghaus RD, Hofacre CL. On farm prevention of Campylobacter and Salmonella: lessons learned from basic biosecurity interventions. J Appl Poult Res. 2015;24(2):222-32. https://doi.org/10.3382/japr/pfv016.

16. Gaucher ML, Quessy S, Letellier A, Arsenault J, Boulianne M. Impact of a drug-free program on broiler chicken growth performances, gut health, Clostridium perfringens and Campylobacter jejuni occurrences at the farm level. Poultry science. 2015;94(8): 1791-801. https://doi.org/10.3382/ps/pev142.

17. Thibodeau A, Fravalo P, Yergeau E, Arsenault J, Lahaye L, Letellier A. Chicken caecal microbiome modifications induced by Campylobacter jejuni colonization and by a non-antibiotic feed additive. PLoS One. 2015;10(7):14. https://doi.org/10.1371/ journal.pone.0131978.

18. Battersby T, Whyte P, Bolton D. Protecting broilers against Campylobacter infection by preventing direct contact between farm staff and broilers. Food Control. 2016;69:346-51. https:// doi.org/10.1016/j.foodcont.2016.04.053.

19. Zhang C, Weiss A, Lin C, Li H, Joerger R, Chiu P. Effects of multiple litter amendment applications in commercial broiler houses on ammonia emissions and litter microflora. Trans ASABE. 2016;59(5):1393-401. https://doi.org/10.13031/trans.59.11725.

20. Baffoni L, Gaggia F, Garofolo G, Di Serafino G, Buglione E, Di Giannatale E, et al. Evidence of Campylobacter jejuni reduction in broilers with early synbiotic administration. Int J Food Microbiol. 2017;251:41-7. https://doi.org/10.1016/j.ijfoodmicro.2017.04.001.

21. Battersby T, Walsh D, Whyte P, Bolton D. Evaluating and improving terminal hygiene practices on broiler farms to prevent Campylobacter cross-contamination between flocks. Food microbiology. 2017;64:1-6. https://doi.org/10.1016/j.fm.2016.11.018.

22. Burbarelli MFD, Polycarpo GD, Lelis KD, Granghelli CA, de Pinho ACC, Queiroz SRA, et al. Cleaning and disinfection programs against Campylobacter jejuni for broiler chickens: productive performance, microbiological assessment and characterization. Poultry science. 2017;96(9):3188-98. https://doi.org/10.3382/ps/ pex153.

23. Corrigan A, Corcionivoschi N, Murphy RA. Effect of yeast mannan-rich fractions on reducing Campylobacter colonization in broiler chickens. J Appl Poult Res. 2017;26(3):350-7. https://doi. org/10.3382/japr/pfx002.

24. Georgiev M, Beauvais W, Guitian J. Effect of enhanced biosecurity and selected on-farm factors on Campylobacter colonization of chicken broilers. Epidemiology and infection. 2017;145(3):55367. https://doi.org/10.1017/s095026881600251x.

25. Ocejo M, Oporto B, Juste RA, Hurtado A. Effects of dry whey powder and calcium butyrate supplementation of corn/soybeanbased diets on productive performance, duodenal histological integrity, and Campylobacter colonization in broilers. BMC veterinary research. 2017;13(1):199. https://doi.org/10.1186/s12917-0171121-5.

26. Wagle BR, Upadhyay A, Arsi K, Shrestha S, Venkitanarayanan K, Donoghue AM, et al. Application of $\beta$-resorcylic acid as potential antimicrobial feed additive to reduce Campylobacter colonization in broiler chickens. Frontiers in microbiology. 2017;8:599. https:// doi.org/10.3389/fmicb.2017.00599.

27. Hankel J, Popp J, Meemken D, Zeiger K, Beyerbach M, Taube V, et al. Influence of lauric acid on the susceptibility of chickens to an experimental Campylobacter jejuni colonisation. PLoS One. 2018;13(9):22. https://doi.org/10.1371/journal.pone.0204483.

28. Huneau-Salaun A, Guyard-Nicodeme M, Benzoni G, Gautier X, Quesne S, Poezevara T, et al. Randomized control trial to test the effect of a feed additive on Campylobacter contamination in commercial broiler flocks up to slaughter. Zoonoses Public Health. 2018;65(4):404-11. https://doi.org/10.1111/zph.12447.

29. Salaheen S, Tabashsum Z, Gaspard S, Dattilio A, Tran TH, Biswas D. Reduced Campylobacter jejuni colonization in poultry gut with bioactive phenolics. Food Control. 2018;84:1-7. https://doi.org/10. 1016/j.foodcont.2017.07.021.

30. Smialek M, Burchardt S, Koncicki A. The influence of probiotic supplementation in broiler chickens on population and carcass contamination with Campylobacter spp. - Field study. Research in veterinary science. 2018;118:312-6. https://doi.org/10.1016/j.rvsc. 2018.03.009.

31. Liu X, Adams LJ, Zeng X, Lin J. Evaluation of in ovo vaccination of DNA vaccines for Campylobacter control in broiler chickens. Vaccine. 2019;37(29):3785-92. https://doi.org/10.1016/j.vaccine. 2019.05.082.

32. Massacci FR, Lovito C, Tofani S, Tentellini M, Genovese DA, De Leo AAP, et al. Dietary Saccharomyces cerevisiae boulardii CNCM I-1079 positively affects performance and intestinal ecosystem in broilers during a Campylobacter jejuni infection. 
Microorganisms. 2019;7(12):21. https://doi.org/10.3390/ microorganisms 7120596 .

33. Skoufos I, Tzora A, Giannenas I, Bonos E, Tsinas A, McCartney E, et al. Evaluation of in-field efficacy of dietary ferric tyrosine on performance, intestinal health and meat quality of broiler chickens exposed to natural Campylobacter jejuni challenge. Livest Sci. 2019;221:44-51. https://doi.org/10.1016/j.livsci.2019.01.008.

34. Tsiouris V, Economou E, Lazou T, Georgopoulou I, Sossidou E. The role of whey on the performance and campylobacteriosis in broiler chicks. Poultry science. 2019;98(1):236-43. https://doi. org $/ 10.3382 / \mathrm{ps} /$ pey388.

35. Atterbury RJ, Gigante AM, Tinker D, Howell M, Allen VM. An improved cleaning system to reduce microbial contamination of poultry transport crates in the United Kingdom. Journal of applied microbiology. 2020;128(6):1776-84. https://doi.org/10.1111/jam. 14576 This study shows evidence that implementing an improved cleaning system for transport coops in a commercial setting is possible and effective in reducing Campylobacter loads.

36. Berrang ME, Meinersmann RJ, Cox NA, Adams ES. Water rinse and flowing steam to kill Campylobacter on broiler transport coop flooring. Food Control. 2020;114:4. https://doi.org/10.1016/j. foodcont.2020.107214.

37. Chinivasagam HN, Estella W, Maddock L, Mayer DG, Weyand C, Connerton PL, et al. Bacteriophages to control Campylobacter in commercially farmed broiler chickens, in Australia. Frontiers in microbiology. 2020;11:632. https://doi.org/10.3389/fmicb.2020. 00632 .

38. Wang C, Zhou H, Guo F, Yang B, Su X, Lin J, et al. Oral immunization of chickens with Lactococcus lactis expressing cjaA temporarily reduces Campylobacter jejuni colonization. Foodborne pathogens and disease. 2020;17(6):366-72. https://doi.org/10. 1089/fpd.2019.2727.

39. de Barros Moreira Filho AL, de Oliveira CJ, de Oliveira HB, Campos DB, Guerra RR, Costa FG, et al. High incubation temperature and threonine dietary level improve ileum response against post-hatch Salmonella enteritidis inoculation in broiler chicks. PLoS One. 2015;10(7):e0131474. https://doi.org/10.1371/journal. pone. 0131474

40. Luyckx KY, Van Weyenberg S, Dewulf J, Herman L, Zoons J, Vervaet E, et al. On-farm comparisons of different cleaning protocols in broiler houses. Poultry science. 2015;94(8):1986-93. https:// doi.org/10.3382/ps/pev143.

41. Mesa D, Lourenco M, Souza A, Bueno A, Pereira A, Sfeir M, et al. Influence of covering reused broiler litter with plastic canvas on litter characteristics and bacteriology and the subsequent immunity and microbiology of broilers. Braz J Poult Sci. 2016;18(4):563-71. https://doi.org/10.1590/1806-9061-2015-0061.

42. Salaheen S, Jaiswal E, Joo J, Peng M, Ho R. D OC, et al. Bioactive extracts from berry byproducts on the pathogenicity of Salmonella Typhimurium. Int J Food Microbiol. 2016;237:128-35. https://doi. org/10.1016/j.ijfoodmicro.2016.08.027.

43. Kloska F, Casteel M, Kump FW, Klein G. Implementation of a riskorientated hygiene analysis for the control of Salmonella JAVA in the broiler production. Current microbiology. 2017;74(3):356-64. https://doi.org/10.1007/s00284-017-1199-9.

44. Muniz EC, Verdi R, Leao JA, Back A. do Nascimento VP. Evaluation of the effectiveness and safety of a genetically modified live vaccine in broilers challenged with Salmonella Heidelberg. Avian Pathol. 2017;46(6):676-82. https://doi.org/10.1080/ 03079457.2017.1348598

45. Vaz CSL, Voss-Rech D, de Avila VS, Coldebella A, Silva VS. Interventions to reduce the bacterial load in recycled broiler litter. Poultry science. 2017;96(8):2587-94. https://doi.org/10.3382/ps/ pex063.
46. Walker GK, Jalukar S, Brake J. Effect of refined functional carbohydrates from enzymatically hydrolyzed yeast on the presence of Salmonella spp. in the ceca of broiler breeder females. Poultry science. 2017;96(8):2684-90. https://doi.org/10.3382/ps/pex054.

47. Hinojosa C, Caldwell D, Byrd J, Droleskey R, Lee J, Stayer P, et al. Use of foaming disinfectants and cleaners to reduce aerobic bacteria and Salmonella on poultry transport coops. Animals : an open access journal from MDPI. 2018;8(11). https://doi.org/10.3390/ ani8110195.

48. Soliman ES, Sallam NH, Abouelhassan EM. Effectiveness of poultry litter amendments on bacterial survival and Eimeria oocyst sporulation. Vet World. 2018;11(8):1064-73. https://doi.org/10.14202/ vetworld.2018.1064-1073.

49. Armwood BT, Rieth A, Baldwin L, Roney CS, Barbieri NL, Logue $\mathrm{CM}$. Assessing the ability of maternal antibodies to protect broiler chicks against colonization by Salmonella Heidelberg. Avian Dis. 2019;63(2):289-93. https://doi.org/10.1637/11970-091218-Reg.1.

50. Clavijo V, Baquero D, Hernandez S, Farfan JC, Arias J, Arevalo A, et al. Phage cocktail SalmoFREE (R) reduces Salmonella on a commercial broiler farm. Poultry science. 2019;98(10):5054-63. https://doi.org/10.3382/ps/pez251.

51. Humam AM, Loh TC, Foo HL, Samsudin AA, Mustapha NM, Zulkifli I, et al. Effects of feeding different postbiotics produced by Lactobacillus plantarum on growth performance, carcass yield, intestinal morphology, gut microbiota composition, immune status, and growth gene expression in broilers under heat stress. Animals. 2019;9(9):20. https://doi.org/10.3390/ani9090644.

52. Jiratitipat N, Srikhong P, Wanasawaeng W, Chansiripornchai N. Efficacy of competitive exclusion to reduce Salmonella in broiler chickens. Thai J Vet Med. 2019;49(4):385-91.

53. Zang YT, Bing S, Li YJ, Shu DQ. Application of slightly acidic electrolyzed water and ultraviolet light for Salmonella Enteritidis decontamination of cell suspensions and surfaces of artificially inoculated plastic poultry transport coops and other facility surfaces. Poultry science. 2019;98(12):6445-51. https://doi.org/10.3382/ps/ pez520.

54. Nguyen DH, Kim IH. Protected organic acids improved growth performance, nutrient digestibility, and decreased gas emission in broilers. Animals. 2020;10(3):11. https://doi.org/10.3390/ ani10030416.

55. Sevilla-Navarro S, Catala-Gregori P, Garcia C, Cortes V, Marin C. Salmonella Infantis and Salmonella Enteritidis specific bacteriophages isolated form poultry faeces as a complementary tool for cleaning and disinfection against Salmonella. Comp Immunol Microbiol Infect Dis. 2020;68:6. https://doi.org/10.1016/j.cimid. 2019.101405.

56. Vaz CSL, Voss-Rech D, Alves L, Coldebella A, Brentano L, Trevisol IM. Effect of time of therapy with wild-type lytic bacteriophages on the reduction of Salmonella Enteritidis in broiler chickens. Veterinary microbiology. 2020;240:108527. https://doi. org/10.1016/j.vetmic.2019.108527.

57. Giannenas I, Bonos E, Anestis V, Filioussis G, Papanastasiou DK, Bartzanas T, et al. Effects of protease addition and replacement of soybean meal by corn gluten meal on the growth of broilers and on the environmental performances of a broiler production system in Greece. PLoS One. 2017;12(1):26. https://doi.org/10.1371/journal. pone.0169511.

58. Granstad S, Kristoffersen AB, Benestad SL, Sjurseth SK, David B, Sorensen L, et al. Effect of feed additives as alternatives to in-feed antimicrobials on production performance and intestinal Clostridium perfringens counts in broiler chickens. Animals. 2020;10(2):19. https://doi.org/10.3390/ani10020240.

59. Roth N, Mayrhofer S, Gierus M, Weingut C, Schwarz C, Doupovec $\mathrm{B}$, et al. Effect of an organic acids based feed additive and enrofloxacin on the prevalence of antibiotic-resistant $E$-coli in 
cecum of broilers. Poultry science. 2017;96(11):4053-60. https:// doi.org/10.3382/ps/pex232.

60. Verrette L, Fairbrother JM, Boulianne M. Effect of cessation of ceftiofur and substitution with lincomycin-spectinomycin on extended-spectrum-beta-lactamase/AmpC genes and multidrug resistance in Escherichia coli from a Canadian broiler production pyramid. Appl Environ Microbiol. 2019;85(13):12. https://doi.org/10. 1128/aem.00037-19.

61. Spoljaric D, Srecec S, Paro MMK, Cop MJ, Mrsic G, Simpragas B, et al. The effects of feed supplemented with Agaricus bisporus on health and performance of fattening broilers. Vet Arh. 2015;85(3): 309-22.

62. Soro AB, Whyte P, Bolton DJ, Tiwari BK. Strategies and novel technologies to control Campylobacter in the poultry chain: a review. Comprehensive Reviews in Food Science and Food Safety. 2020;19(4):1353-77. https://doi.org/10.1111/1541-4337.12544 This study provides a review on post-harvest and novel technologies to control Campylobacter.

63. Anon. Prevention, Detection and Control of Salmonella in Poultry, Terrestrial Animal Health Code. 28th ed., 2019.

64. Hopp P, Wahlstrom H, Hirn J. A common Salmonella control programme in Finland, Norway and Sweden. Acta veterinaria Scandinavica. 1999:45-9.

65. Guyard-Nicodeme M, Keita A, Quesne S, Amelot M, Poezevara T, Le Berre B, et al. Efficacy of feed additives against Campylobacter in live broilers during the entire rearing period. Poultry science. 2016;95(2):298-305. https://doi.org/10.3382/ps/pev303.

66. Micciche A, Rothrock MJ Jr, Yang Y, Ricke SC. Essential oils as an intervention strategy to reduce Campylobacter in poultry production: a review. Frontiers in microbiology. 2019;10:1058. https://doi.org/10.3389/fmicb.2019.01058.

67. Dorado-Garcia A, Smid JH, van Pelt W, Bonten MJM, Fluit AC, van den Bunt G, et al. Molecular relatedness of ESBL/AmpC-producing Escherichia coli from humans, animals, food and the environment: a pooled analysis. J Antimicrob Chemother. 2018;73(2): 339-47. https://doi.org/10.1093/jac/dkx397.

68. EFSA. Scientific Opinion of the Panel on Biological Hazards on a request from EFSA on monitoring of verotoxigenic Escherichia coli (VTEC) and identification of human pathogenic VTEC types. The EFSA Journal. 2007;579:1-61.

69. Kalin R, Ongor H, Cetinkaya B. Isolation and molecular characterization of Escherichia coli $\mathrm{O} 157$ from broiler and human samples. Foodborne pathogens and disease. 2012;9(4):313-8. https://doi. org/10.1089/fpd.2011.0991.

70. Nesbakken T. Update on Yersinia as a foodborne pathogen: analysis and control. Advances in Microbial Food Safety. 2015:33-58.

71. Monteiro Pires S, Jakobsen LS, Ellis-Iversen J, Pessoa J, Ethelberg S. Burden of disease estimates of seven pathogens commonly transmitted through foods in Denmark, 2017. Foodborne pathogens and disease. 2020;17(5):322-39. https://doi.org/10.1089/fpd.2019. 2705.

72. Dubey JP. Toxoplasma gondii infections in chickens (Gallus domesticus): prevalence, clinical disease, diagnosis and public health significance. Zoonoses Public Health. 2010;57(1):60-73. https://doi.org/10.1111/j.1863-2378.2009.01274.x.

Publisher's Note Springer Nature remains neutral with regard to jurisdictional claims in published maps and institutional affiliations. 